\title{
Evaluation of food habits and information levels of elite table tennis players and trainers
}

\author{
Oktay CIMEN ${ }^{1}$, Metin KAYA ${ }^{1}$, Cengiz TASKIN²
}

${ }^{1}$ School of Physical Education and Sport, Gazi University, Ankara, Turkey.

${ }^{2}$ School of Physical Education and Sport, Batman University, Batman, Turkey.

Address correspondence to Metin KAYA, mkaya@gazi.edu.tr

This study was summarized from O. Cimen's Doctoral thesis.

\begin{abstract}
The aim of the study was to assess food habits and information levels of elite table tennis players and trainers. The universe of the study involves table tennis sportsmen and trainers; its sample involves 94 sportsmen and 44 trainers randomly chosen from the universe as well. The research is of a screening model directed to the situation determination. The data collection tool used in this research consists of 3 sections. In the first section, a personal information form was developed to show the participants' demographic characteristics by the researcher. In the second section, food habits were given and in the third section a questionnaire for measuring food information was applied. The questionnaire questions were arranged by screening the relevant literature, taking expert opinions and studying the questionnaires about food used in master and doctorate thesis before, thus the Cronbach's alpha value was regarded to be "0.722" from the reliability analysis. When trainers and sportsmen' food information and food habits were compared in genders, it was seen that there were not any significant differences both females and males being trainers and females and males still doing sport $(\mathrm{P}>0.05)$. When food information and food habits were also compared in trainers and sportsmen, it was observed that there was a statistically significant difference between trainers and sportsmen $(\mathrm{P}<0.05)$. In conclusion, it was understood that sportsmen's food information was better than trainers' food information as trainers' food habits were better than sportsmen's food habits.
\end{abstract}

Key Words: Food, sportsmen, table tennis, trainer.

\section{INTRODUCTION}

Nutrition is a consumption of foods in order to fulfill vital functions, grow up, develop, reproduce, perform physical activities and keep fit, shortly go on living (7). It is possible for a sportsman to develop one's body, keep healthy and have a high sportive productivity only when he eats in a balanced, regular and purpose way (16). It is suggested that failures with unknown reasons or non-optimal performances mostly depend on inappropriate nourishment. And it is known that expectations of high productivity from sportsmen will be achieved in taking food nutrients adjusted as appropriate doses quantitatively and qualitatively when considering the relevant trainings and competition conditions (4). By making arrangements about trainings and competition periods in accordance with a sportsman's gender, age, daily physical activity and doing sport type, it is very important to eat foods enough and in a balanced way (7). A sportsman's nourishment must have some features in terms of calorie and quality in accordance with sport type. The aim is to meet need of energy through carbohydrates and fats, to respond to need of protein when creating, protecting and repairing tissues and to provide necessary vitamins and minerals when carrying food nutrients in body and creating enzymes (10). Table tennis is among sport branches requiring a quick power (10). In this regard, sportsmen's diet applications must be prepared under the general nourishment criteria before, during and after both trainings and competitions. A table tennis sportsman's daily need must be considered to be $3.500-4.000 \mathrm{k} / \mathrm{kal}$ and the need of energy may show increases or decreases depending on the characteristics of training and competition. Thus, the aim of this study was to assess food habits and information levels of elite table tennis players and trainers. 


\section{MATERIAL \& METHODS}

The universe of the study involves table tennis sportsmen and trainers; its sample involves 94 sportsmen and 44 trainers randomly chosen from the universe as well. The research is of a screening model directed to the situation determination. According to Karasar (8), the screening model is a research approach used to describe a historical or still current situation as it is. The data collection tool used in this research consists of 3 sections. In the first section, a personal information form was developed to show the participants' demographic characteristics by the researcher. In the second section, food habits were given and in the third section a questionnaire for measuring food information was applied. The questionnaire questions were arranged by screening the relevant literature, taking expert opinions and studying the questionnaires about food used in master and doctorate thesis before, thus the Cronbach's alpha value was regarded to be " 0,722 " from the reliability analysis.

\section{Statistical Analysis}

The scale forms collected by the researcher were controlled, these ones which were filled in a missing or wrong way, was excluded from the research. Then the valid and acceptable ones were computerized in order to evaluate them in SPSS package program. In assessment of research data, the participants' demographic characteristics obtained from the personal information form, the frequencies and percentage distributions of the questions related with food information and food habits were analyzed. Also, "the independent t-test for two samples" was performed to understand whether there were differences about food information and food habits between sportsmen and trainers. When examining the sub-problems from the 37 demographic characteristics of the participants, the Independent Samples Test, the Kruskal Wallis Test and the ANOVA were done to determine differences between food information and food habits included in the questionnaire items in accordance with gender, education level, license and regular sportive activities.

In comparison of trainers and sportsmen's food information and food habits to the genders, it was determined that there were not any statistically significant differences between both male and female trainers, both male and female sportsmen $(\mathrm{P}>0.05)$.

In comparison of trainers and sportsmen in terms of food information and food habits, there was a statistically significant difference between trainers and sportsmen $(\mathrm{P}<0.05)$. Within these comparisons, sportsmen's food information was understood to be better than trainers' food information as trainers' food habits were considered to be better than sportsmen's food habits.

\section{RESULTS}

Table 1. Comparison of trainers and sportsmen's food habits and food information in accordance with the gender variable.

\begin{tabular}{|c|c|c|c|c|c|c|}
\hline Groups & Variables & Gender & Average & $\begin{array}{l}\text { Standard } \\
\text { Deviation }\end{array}$ & $\mathrm{T}$ & $\mathrm{P}$ \\
\hline \multirow[t]{4}{*}{ Trainers } & \multirow[t]{2}{*}{ Food Habits } & Male $(\mathrm{N}=31)$ & 25.516 & 1.912 & \multirow[t]{2}{*}{-0.374} & \multirow[t]{2}{*}{0.710} \\
\hline & & Female(N=13) & 23.769 & 2.350 & & \\
\hline & \multirow[t]{2}{*}{ Food Information } & Male(N=31) & 28.354 & 1.450 & \multirow[t]{2}{*}{0.260} & \multirow[t]{2}{*}{0.796} \\
\hline & & Female(N=13) & 28.230 & 1.423 & & \\
\hline \multirow[t]{4}{*}{ Sportsmen } & \multirow[t]{2}{*}{ Food Habits } & Male(N=64) & 22.328 & 2.323 & \multirow[t]{2}{*}{-1.122} & \multirow[t]{2}{*}{0.569} \\
\hline & & Female(N=30) & 22.996 & 3.045 & & \\
\hline & \multirow[t]{2}{*}{ Food Information } & Male $(\mathrm{N}=64)$ & 27.656 & 2.169 & \multirow[t]{2}{*}{-0.390} & \multirow[t]{2}{*}{0.697} \\
\hline & & Female(N=30) & 27.833 & 1.763 & & \\
\hline
\end{tabular}

Table 2. Comparison of trainers and sportsmen in terms of food habits and food information.

\begin{tabular}{|c|c|c|c|c|c|}
\hline Variables & & Average & Standard Deviation & $\mathrm{T}$ & $\mathrm{P}$ \\
\hline Food Habits & $\begin{array}{l}\text { Trainers }(\mathrm{N}=44) \\
\text { Sportsmen }(\mathrm{N}=94)\end{array}$ & $\begin{array}{l}23.591 \\
22.532\end{array}$ & $\begin{array}{l}1.427 \\
2.041\end{array}$ & 2.399 & $0.018^{*}$ \\
\hline Food Information & $\begin{array}{l}\text { Trainers }(\mathrm{N}=44) \\
\text { Sportsmen }(\mathrm{N}=94)\end{array}$ & $\begin{array}{l}23.318 \\
27.713\end{array}$ & $\begin{array}{l}1.426 \\
2.040\end{array}$ & 2.012 & $0.047^{*}$ \\
\hline
\end{tabular}




\section{DISCUSSION}

A statistically significant difference was found in food information level and food habits between trainers and sportsmen in this study which aimed to determine elite table tennis players and trainers' food habits and food information $(\mathrm{P}<0.05)$.

In Pulur \& Cicioğlu's study (11) on food information and habits of female basketball players playing at different leagues in Ankara, $40 \%$ of the subjects showed their trainers as a resource of information about a sportsman's nourishment. The other resources were a sportsman's friends, school, book, newspaper, journal and TV, respectively. Süel et al. (13) determined that there was not a difference in food habits between elite female basketball players and male basketball players playing at $1^{\text {st }}$ league. In accordance with Yılmaz's study (17) findings about football players, he concluded that football players involved in the study gave importance to eat regularly, did not skip main drives and knew about the importance of nourishment.

It was stated that it should be 3-4 hours between the latest eating and the competition for $100 \%$ of professional football players and $92.5 \%$ of amateur football players in Göral's study, for $100 \%$ of professional football players and $95 \%$ of amateur football players in Öztürk's study as well. While $86,7 \%$ of all football players suggested $2-4$ hours between the latest eating and the competition, the research by Bayrakdar et al. (3) also claimed that $88 \%$ of players suggested to have approximately 3 hours between the latest eating and the competition.

Yarar et al. (15) suggested that 56,5\% of sportmen had information about nourishment, similarly, Pulur \& Cicioğlu (11)also stated that 54\% of sportmen had information about a sportsman's nourishment, Atay et al. (2) explained that $73,7 \%$ of football players had a great information about nourishment. It was given that elite sportmen interested in sport for a long time were not informed enough about nourishment (14). Furthermore, Cotunga (5) said that sportsmen did not have any enough information about nourishment though they generally cared about it. Rosenbloom et al. (12) measured food information levels of sportsmen aged 19 on average in 385 different branches and found that sportsmen's food information levels were not adequate.

In Abood et al.'s study (1), sportsmen were randomly chosen from a female football team and female swimming team in Florida, their food information levels were measured, and then sportsmen's food levels were regarded to be unsatisfying. Sportsmen's food information was only training-targeted. Süel et al. (14) studied that basketball players were not so informed about eating healthy.

In conclusion, sportsmen's food information was understood to be better than trainers' food information as trainers' food habits were considered to be better than sportsmen's food habits. In a branch of Table Tennis, there are less trainers and sportsmen graduated from the School of Physical Education and Sport. Especially, trainers who have an important place about sportsmen's performance and nourishment, have less information about a sportsman's nourishment since they are not graduates of the School of Physical Education and Sport and do not take any lessons about a sportsman's nourishment in these types of schools.

\section{REFERENCES}

1. Abood DA. Black RD. Birnbaum RD. Nutrition education intervention for college female athletes. J. Nutr. Educ. Behav. 2004; 36(3): 135-139.

2. Atay E. Kılınç F. Çetinkaya E. Kılıç T. Türkiye Yarı Finallerine Katılan Yıldızlar Kategorisi Ilköğretim Okulları Futbolcularının Beslenme Alışkanlık Düzeylerinin İncelenmesi. 9. Uluslararası Spor Bilimleri Kongresi. Bildiri Kitapçı̆̆ı. 2006; 475-477. Muğla.

3. Bayrakdar A. Saygın Ö. Karacabey K. Gelen E. Üniversite öğrencilerinin beslenme bilgi ve alışkanlıklarının incelenmesi. 1. Adli Bilimler ve Spor Kongresi. Bildiri Kitapçı̆̆ı. 2008; Ankara.

4. Bulduk S. Yabancı N. Değirmencioğlu Y. Özel Durumlarda Beslenme. Ya-Pa Yayınları. İstanbul. 2002.

5. Cotugna N. Connie EV. McBee S. Sports nutrition foryoung athletes. The Journal of School Nursing. 2005; 21 (6):323-328.

6. Göral K. Farklı Liglerde Oynayan Futbolcuların Beslenme Alışkanlıkları ve Bilgi Düzeylerinin İncelenmesi. Muğla Üniversitesi Sosyal Bilimler Enstitüsü. Beden Eğitimi ve Spor Anabilim Dalı. Yüksek Lisans Tezi.. Muğla. 2008.

7. Güneş Z. Spor ve Beslenme. Antrenör ve Sporcu El Kitabı. Ankara: Bağırgan Yayınevi. 1998.

8. Karasar N. Bilimsel Araştırma Yöntemi. Nobel. Ankara. 2002.

9. Öztürk A. Profesyonel ve amatör futbolcuların beslenme alışkanlıkları ve vücut bileşimleri. Cumhuriyet Üniversitesi Sosyal Bilimler Enstitüsü. Yüksek Lisans Tezi. Sivas. 2006.

10. Paker S. Sporda Beslenme. 3. Basım. Gen Matbaacılik. Ankara. 1996.

11. Pulur A. Cicioğlu İ. Nutritional knowledge and habits of female basketball players. Atatürk Üniversitesi BESBD. 2001; $1(2) ; 44-47$.

12. Rosenbloom CA. Jonnalagadda SS. Skinner R. Nutrition knowledge of collegiate athletes in a division I National Collegiate Athletic Association Institution. J. Am. Diet. Assoc. 2002; 102 (3): 418-420. 
13. Süel E, Sahin I, Karakaya MA, Savucu Y. The nutritional knowledge and habits of basketball players in elit level. Firat University Journal of Health Sciences (Medicine), 2006; 20(4) 271-275

14. Süel E. Şahin İ. Üniversite düzeyindeki bayan ve erkek basketbolcuların beslenme bilgilerinin ve alışkanlıklarının belirlenmesi. 9. Uluslararası Spor Bilimleri Kongresi. . Kongre Bildiri Kitapçı̆̆ı. 2006; 451-453. Muğla.

15. Yarar H. Gökdemir K. Eroğlu H. Özdemir G. Evaluation of knowledge for diet and dietary habits of elite athletes. Selcuk University J Physical Education and Sport, 2011; 13(3); 368371.
16. Yıldıran İ. Dayanıklılık yüklenmelerinde enerji kullanim yollari ve enerji kaynakları. Gazi Eğitim Fakültesi Dergisi. 1992; 8(1); 93-98.

17. Yılmaz G. Niğde Üniversitesi Beden Eğitimi ve Spor Yüksek Okulu Öğrencilerinin Beslenme ve Kahvaltı Alışkanlıklarının Değerlendirilmesi. Niğde Üniversitesi Sosyal Bilimler Enstitüsü. Yüksek Lisans Tezi. Niğde. 2002. 